\title{
Antioxidant Activity Correlated with Chlorophyll Pigments and Magnesium Content of Some Green Seaweeds
}

\section{T. Negreanu-Pirjol}

“Ovidius” University of Constanta, Faculty of Pharmacy, Constanta, Romania

R. Sirbu

“Ovidius” University of Constanta, Faculty of Pharmacy, Constanta, Romania

M. Mirea

“Ovidius" University of Constanta, Faculty of Pharmacy, Constanta, Romania

B.S. Negreanu-Pirjol

“Ovidius” University of Constanta, Faculty of Pharmacy, Constanta, Romania

\section{Abstract}

The complex valorification of seaweed biomass represents a highly important resource for the pharmaceutical and dermo-cosmetic industry, supplying raw material for the extraction of bioactive substances such as, polysaccharides, vitamins, sterols, aminoacids, polyphenols and minerals. Marine algae represent an indefatigability resource of therapeutic active principles for diseases treatment of magnesium deficiency. The presence of chlorophyll pigments in the green algae confirms the magnesium existence, as central element in molecular structures. The main green algae, as Ulva lactuca and Enteromorpha intestinalis present on the Romanian Black Sea Coast, belong to Chlorophyta sp. In this paper we present a study of antioxidant activity correlated with magnesium content and chlorophyll pigments of the green algae Enteromorpha intestinalis and Ulva rigida (syn. Ulva lactuca) hydroalcoholic extracts. For chlorophyll pigments determination, the UV-Vis spectrometry was used. Magnesium content had been determined by absorption atomic spectrometry method, using HR-CS- AAS ContraA 700 apparatus, Analytik Jena and for total antioxidant capacity of green algae extracts, the photochemiluminescence method had been applied, using Photochem Analytik Jena apparatus. The comparative studies on two marine green algae extracts confirm the high magnesium content correlated with a high level of total antioxidant capacity for both species. The results obtained emphasize the possibility to enlarge the options to use these natural vegetal resources from Black Sea Coast, in different degenerative diseases therapy. 
Keywords: marine algae extracts, chlorophyll pigments, magnesium content, antioxidant activity

\section{Introduction}

Marine algae represent an unequaled nutrients dietary source, [1]. The presence of chlorophyll pigments in the green algae confirms the magnesium existence, as central element in molecular structures. The literature mentions that marine green algae are an important resource, a therapeutic bioactive and source of antioxidants principles, such as proteins, oligominerals, vitamins, polyphenols, polysaccharides (e.g. agaragar, alginats), fatty acids, fibers, [2]. All of these biocomponents stimulate the endocrine glands, blood circulation and immune system, are alkalinizing, remineralizing, antirheumatic, antiinfectious, antiaging. Their therapeutic action is to improve digestion, detoxify the body, accelerate healing, provide radiation protection, help prevent degenerative diseases and attenuate arthritic pain. Also, the rich content of chlorophyll pigments from green seaweeds, gives them the natural adjuvant status of the body in detoxification and healing processes. Magnesium is a versatile mineral that has some major implications, in the human body ranks fourth in overall abundance, but intracellular it is second only to potassium. Between $60-65 \%$ of magnesium in the human body is present in bone. Magnesium that does not exist as part of bone is mainly present within muscle intracellular. About $1 \%$ of magnesium is present in the extra cellular fluid. Inside cells, magnesium may be found bound to phospholipids. This mineral is involved in over 300 enzymatic reactions in the body including glycolysis, the Krebs cycle, creatine phosphate formation, nucleic acid synthesis, amino acid activation, cardiac and smooth muscle contractibility, cyclic AMP formation, and protein synthesis. There is a close relationship of reciprocity between the shortage of magnesium and long-states stress, as in the senescence. In contemporary medicine, there is an increased interest regarding magnesium, as this macroelement seems to be involved though various metabolic circuits in the prophylaxis of a large number of diseases, [3 - 5, 10 - 13].

In this paper, we present a study regarding chlorophyll pigments and magnesium content correlated content with total antioxidant capacity of some green algae, specifics for Romanian Black Sea Coast, belong to Chlorophyta species, such as Cladophora vagabunda (L.) Hoek. and Ulva lactuca Ag. syn. Ulva rigida (L.).

Ulva lactuca (syn. Ulva rigida) is a small genus of marine and brackish water green algae in the Ulvaceae family. It is edible and is often called sea lettuce. The dark to pale green thallus of ulvoid species is flat and blade-like and is composed of two layers of cells. There is no differentiation into tissues; all the cells of the plant are more or less alike except for the basal cells, which are elongated to form attachment rhizoids. Each cell contains one nucleus and has a cup-shaped choroplast with a single pyrenoid. Plants tend to be pale green when young, bright green when mature and dark green 
when old. Ulva lactuca can be up to $45 \mathrm{~cm}$ long and $30 \mathrm{~cm}$ across, can be used in cooking, soups, with meats and fish, and salads, $[6-8,10]$.

Cladophora vagabunda (L.) Hoek, pale green to grass green alga, present filamentous thallus, spongy, soft tufts, anywhere from $5-50 \mathrm{~cm}$ in length. The plants are small, broom-like in shape and grow to be to $3-4 \mathrm{~cm}$ tall. This species grows on rocks in mid to lower intertidal zones along moderately wave exposed shorelines. Are opportunistic settlers that respond to environmental variations, [9-13].

\section{Material and Methods}

The studied algal material were manual harvested from the South Romanian Coast of Black Sea, sector between Mangalia - 2 Mai - Vama Veche, the medio-littoral area, in the period July - August 2018, Fig. 1. The green algae biomass was collected in the morning when is a maximum of UV rays, at the temperature between $28^{\circ} \mathrm{C}$ in July and $25^{\circ} \mathrm{C}$ in August 2018. Vegetal product was sorted on species, Ulva lactuca Ag. syn. Ulva rigida (L.) and Cladophora vagabunda (L.) Hoek. The immediately pretreatment process after harvesting involves washing the biomass thoroughly several times with distillated water, to remove adhering sand particles and impurities and dried at room temperature, for 24 hours, in the dark. Fresh marine algae biomass was weighed to determine the loss of water through drying process, [14].

The dried algae material was macerated to a fine powder (homogeneous, as well as a higher surface-to-volume ratio) and analyzed for chlorophyll pigments content, magnesium content and total antioxidant capacity, with triplicate samples of each determination.

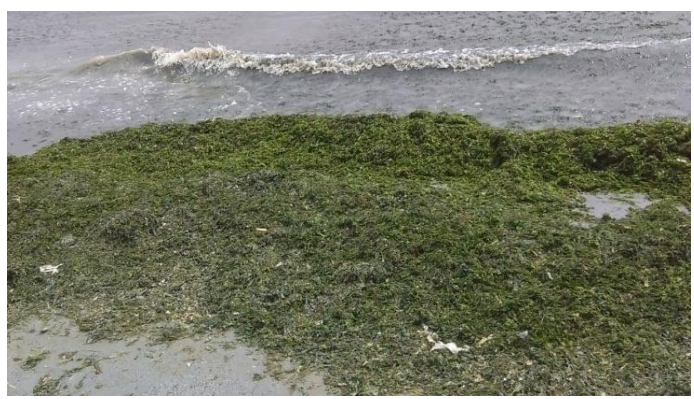

Fig. 1. Green seaweed biomass along South Romanian Black Sea Coast
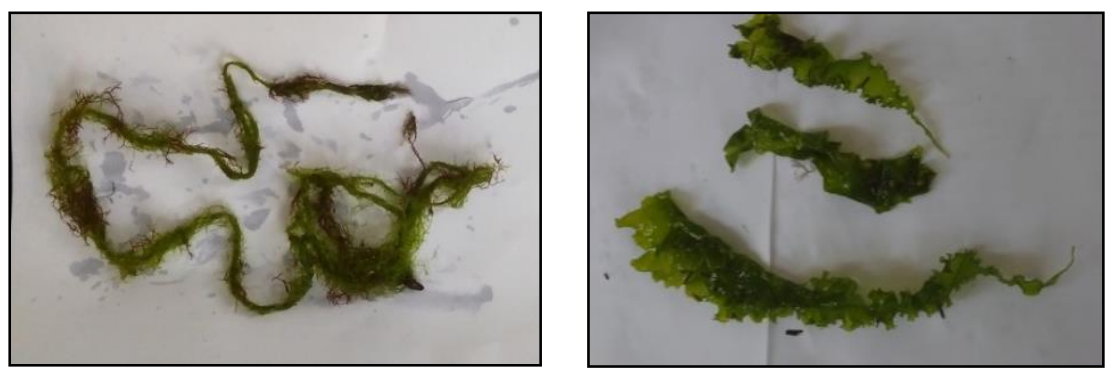
Fig. 2. Green seaweeds species: Cladophora vagabunda (L.) Hoek. (a); Ulva lactuca Ag. syn. Ulva rigida (L.)

\section{Macroalgae chlorophylls pigments determination}

- Algal thallus was cut into small fragments. $0.1 \mathrm{~g}$ of each sample was ground in $80 \%$ acetone, with sand grains for higher efficiency and

incubated in darkness at ambient temperature, for complete extraction. The final extracts in concentration $10 \%$ of marine algae, were filtered through a blue band Whatman filter paper. Chlorophyll pigments content by UV-Vis Spectrophotometric method, at specific wavelengths $647 \mathrm{~nm}$ and $663 \mathrm{~nm}$, using a WPA S106 spectrometer were determined, with $80 \%$ acetone as blank. The concentrations of chlorophyll $a$ and chlorophyll $b$ were calculated by using specific equations according to Lichthenthaler and Buschmann Subsequently, the amount of chlorophyll/g of algal material was calculated, $[15,16,17]$.

\section{Macroalgae magnesium content determination}

- Sample preparation. Solid samples were dried until $105^{\circ} \mathrm{C}$, in order to reach constant mass. For mineralization after decantation, samples

were filtered on Whatman quantitative filter paper. After drying, marine biomass algae samples were mineralized with concentrated acids in order to determine the presence and concentration of metallic elements, at controlled temperature and pressure in the digestion system. After finishing this process, the content of the digestion vessels was introduces in $25 \mathrm{~mL}$ marked flacks and brought to volume with twice-distilled and deionized water. The controls for the AAS methods were: 1 sample of concentrated acids (with variable volumes, depending on the type of analysed sample), subjected to digestion process, consisting in the following mixture: $2 \mathrm{~mL}$ $\mathrm{H}_{2} \mathrm{SO}_{4} 96 \%, 2 \mathrm{~mL} \mathrm{H}_{3} \mathrm{PO}_{4} 85 \%$, $2 \mathrm{~mL} \mathrm{HF} 40 \%$ and $1 \mathrm{~mL} \mathrm{HNO}{ }_{3} 65 \%$.

-Concentrations of magnesium were measured using atomic absorption spectrometry methods. All the materials foreseen for these analytical

determinations comply with the quality standards in force. Apparatus: High Resolution Continuum Source Atomic Absorption Spectrometer ContrAA 700, Analytik Jena AG, Germany, with autosampler for dilution sample, on acetylene flame technique, sequential analysis, at specific wavelengths $285.2125 \mathrm{~nm}$. Furnace parameters: Pyrolysis Temperature: $850{ }^{\circ} \mathrm{C}$; Atomization Temperature: $1500{ }^{\circ} \mathrm{C}$; Samples and standards were diluted with ultrapure deionized water, $[15,18,19]$.

\section{Macroalgae total antioxidant capacity determination}

- Sample preparation. To determine total antioxidant capacity of the vegetal samples, the stock solution was prepared as follows: well-dried algae were ground, triturated to fine powder, then a cold extract of each species of algae was got, using $1 \mathrm{~g}$ and respectively $10 \mathrm{~g}$ of dry vegetable raw material (algal species), which were placed in 
volumetric flasks $(100 \mathrm{~mL})$ and made up to the mark with $70 \%$ ethylic alcohol. Extraction was performed for 12 days, at room temperature, at darkness. Mixtures were shaken regularly and separation of extracts was done by decanting, then were filtered under normal pressure on a blue band Whatman filter paper. Resulted 1\% and $10 \%$ concentration of fluid extracts, herein after referred to as clear, with specific algae odor and color depending on species. Before to the measurement, the samples were rapidly homogenized using a Vortex Velp Scientifica, Italy agitator and $10 \mu \mathrm{L}$ volume of the sample were taken from the supernatant. Each determination lasted 120 seconds, [18, 21, 22].

- Total antioxidant capacity (TEAC) determination - the photochemiluminescence method by ACL (Antioxidative Capacity in Lipid Soluble Substances) procedure Analytik Jena AG, Germany, using Photochem apparatus, for the hydroalcoholic extracts of $1 \%, 10 \%$ in ethyl alcohol concentration $70 \%$, repeated in triplicate and quantified by comparison with the standard Trolox®, Hoffman-LaRoche's trade name (6-hydroxy-2,5,7,8-tetramethylchroman-2-carboxylic acid) vitamin E derivative, were performed. For the calibration curve, standard reagents kit, Analytik Jena Germany was used: R1 (dilution solvent), R2 (buffer reagent), R3 (photosensitive reagent), R4 (reagent sized). The calibration curve was done by measuring a series of standard solutions containing 0.5, 1.0, 2.0, $3.0 \mathrm{nmol}$ Trolox (suitable for $5-30 \mu \mathrm{L} \mathrm{R}$ ), Fig. 3, [18].

Exposure to external radiation from a Hg lamp lined with phosphor that provides the maximum energy at $\lambda=351 \mathrm{~nm}$, photosensitive reagent, produces free radicals in the sample for analysis, resulting a photochemical reaction. The free radicals (superoxide anion radicals) produced by optical excitation of a photosensitized substance added in standardized volumes, are partially eliminated by reaction with the antioxidants present in the sample. The residual radicals cause the detector substance to luminescence, which is then exactly determined in a separate cell by means of a photomultiplier tube. The measuring signal produced by the luminescence is traced over $3 \mathrm{~min}$. The total antioxidant capacity of the sample is measured by converting the electrical signal which is then converted into concentration values and is quantified by comparison with the standard Trolox® expressed as Trolox equivalency $\mathrm{nmol} / \mathrm{sample}$, [21 - 29].

Apparatus: Photochemiluminometer PHOTOCHEM Analytik Jena AG, Germany.

From stock solution were prepared the samples, as follow (Table 1):

Table 1. Working scheme (volumes in $\mu \mathrm{L}$ ), [28]

\begin{tabular}{llllll}
\hline Reagent & R1 & R2 & R3 & R4 & Sample \\
\hline Blank & 2.300 & 200 & 25 & 0 & 0 \\
\hline Calibration curve & $2.300-$ vol. $(\mu \mathrm{L})$ & 200 & 25 & vol. $(\mu \mathrm{L})$ & 0 \\
\hline $\begin{array}{l}\text { Measurement } \\
\text { samples }\end{array}$ & $2.300-$ vol. $(\mu \mathrm{L})$ & 200 & 25 & 0 & vol. $(\mu \mathrm{L})$ \\
\hline
\end{tabular}




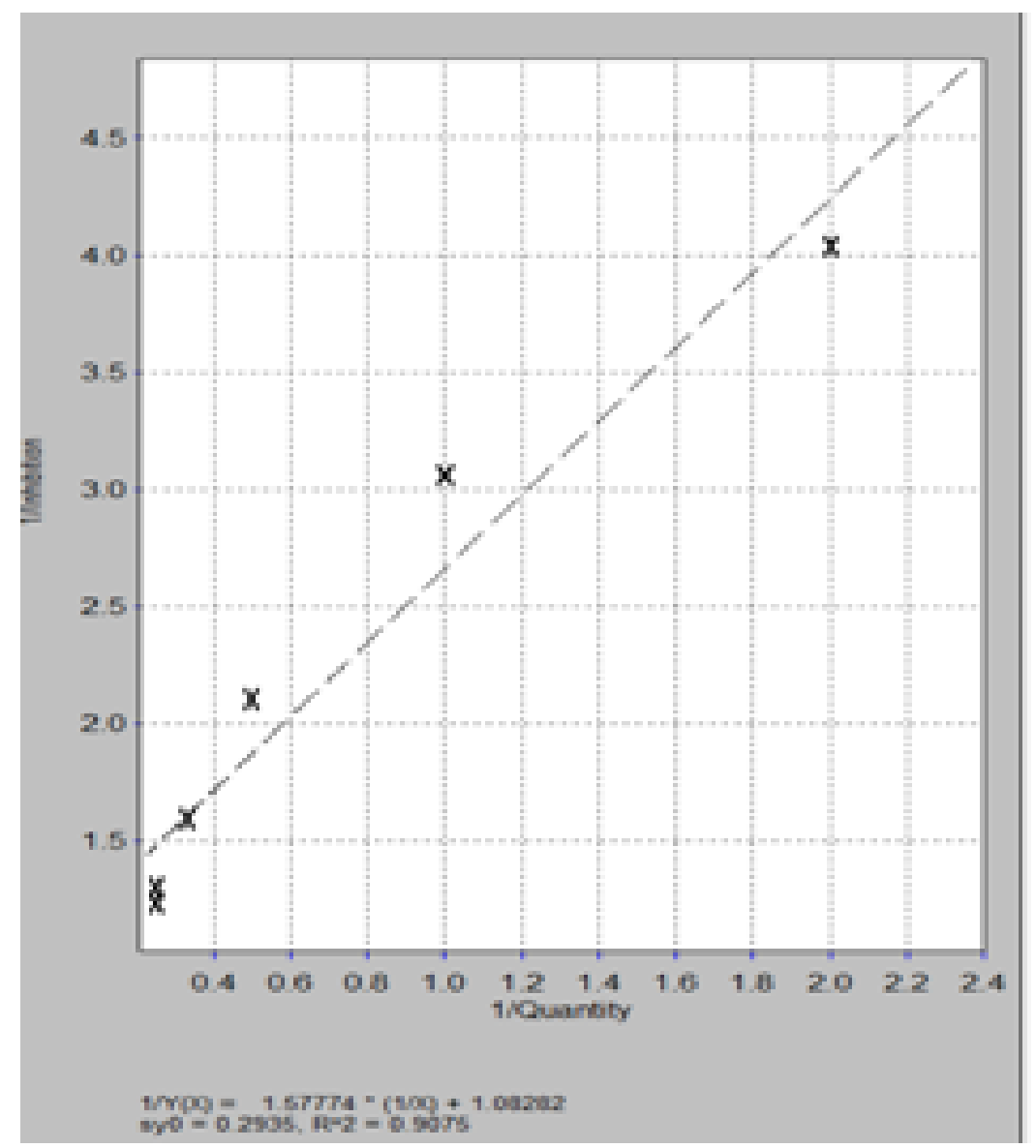

Fig. 3. Calibration curve for standard Trolox (ACL method, Analytik Jena AG)

\section{Results and Discussions}

Macroalgae pigments content determination

Chlorophylls pigments contents of green algae fluid extracts from Mangalia - 2 Mai Vama Veche area, at $10 \%$ concentration of algal extracts, emphasize an increased values. Chlorophyll $a$ and chlorophyll $b$ content presented high values for both species, Fig. 4.

- For Cladophora vagabunda L. Hoek high value of chlorophyll a (59.88207 mg/L) compared to Ulva lactuca L. (16.3455 mg/L) was registered, respectively for Cladophora vagabunda L. Hoek high value of chlorophyll $b(48.24553 \mathrm{mg} / \mathrm{L})$ compared to Ulva lactuca L. (8.595833 mg/L) was registered. 


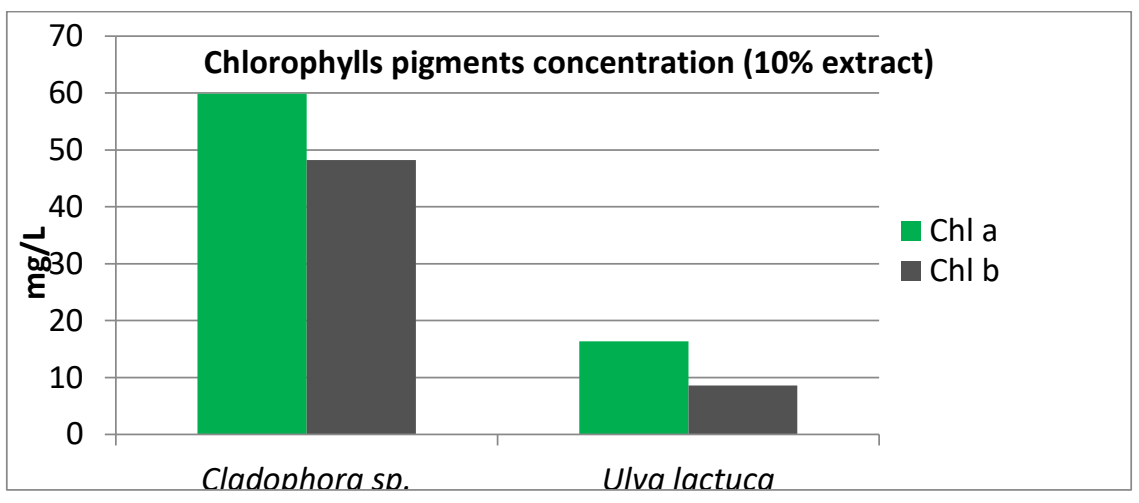

Fig. 4. Chlorophyl pigments concentration (10\% extract)

\section{Magnesium content determination}

- The results obtained emphasize that magnesium content was increased for both algae species.

- For Cladophora vagabunda L. species, a higher content of magnesium (56 mg/L) compared to that presents in Ulva lactuca L. species ( $48 \mathrm{mg} / \mathrm{L})$, at the same extracts concentration $10 \%$ algae, was registered.

\section{Total antioxidant capacity (TEAC)}

- Total antioxidant capacity (TEAC) of algae fluid extracts was reported according to the ACL procedure, quantified by comparison with standard substance Trolox. The results are expressed in nmol/vol. sample, Trolox equivalent units, according to Table 2.

Table 2. Antioxidant capacity compared to Trolox (ACL method)

\begin{tabular}{lllll}
\hline Sample & $\begin{array}{l}\text { Sample } \\
\text { volume } \\
\text { used } \\
(\mu \mathrm{L})\end{array}$ & $\begin{array}{l}\text { Analysis } \\
\text { time } \\
(\mathrm{sec} \text { ) }\end{array}$ & $\begin{array}{l}\text { Maximum } \\
\text { inhibition } \\
\text { radicals }\end{array}$ & $\begin{array}{l}\text { Trolox } \\
\text { equivalent units } \\
\text { (nmol/volume } \\
\text { sample) }\end{array}$ \\
\hline $\begin{array}{l}\text { Cladophora } \\
\text { vagabunda 1\% }\end{array}$ & 10 & 120 & 0.224 & 0.715 \\
\hline $\begin{array}{l}\text { Cladophora } \\
\text { vagabunda 10\% }\end{array}$ & 10 & 120 & 0.316 & 0.823 \\
\hline Ulva lactuca 1\% & 10 & 120 & 0.162 & 0.489 \\
\hline Ulva lactuca 10\% & 10 & 120 & 0.131 & 0.544 \\
\hline
\end{tabular}

The obtained experimental results highlight the following aspects:

- The extraction method used to obtain fluid extracts, cold maceration in $70 \%$ ethyl alcohol for 12 days in the dark, generated an increased total antioxidant capacity.

- At concentration $10 \%$ of the extracts, both algae species present an increased total antioxidant capacity. 
- The highest antioxidant capacity values was recorded for Cladophora vagabunda algae $10 \%$ concentration $(0.823 \mathrm{nmol} / \mathrm{vol}$. sample $)$, compared with the lowest obtained values for Ulva lactuca algae $10 \%$ concentration ( $0.544 \mathrm{nmol} / \mathrm{vol}$. sample).

- Ulva lactuca algae samples emphasize the lowest antioxidant capacity at $1 \%$, respectively $10 \%$ concentrations of the extracts.

- The behavior observed for the two studies seaweeds, could be correlated with the highest content in magnesium and chlorophylls of Cladophora vagabunda species compared with decreased content for Ulva lactuca species. The obtained values are in accordance with literature $[21,22]$.

\section{Conclusion}

Regarding the two studied green seaweeds species present along South Romanian Black Sea Coast, Cladophora vagabunda (L.) Hoek. registered an increased values of chlorophyll pigments and magnesium content compared to those for Ulva lactuca (L.); Also, both algae species present a high antioxidant activity, most intensive being at the Cladophora vagabunda (L.) Hoek. The results obtained emphasize the possibility of opening new directions in the process of complex valorification of these bioresources offered by the Black Sea, for obtaining new pharmaceutical and dermato-cosmetic products from available natural resources of Romanian littoral.

Acknowledgments: The authors would like to express appreciation for the financial support of the Romanian Ministry of Research - UEFISCDI, for Complex Project no. 85 PCCDI/2018, Acronym INOBIOMAR, Project code PN-III-P1-1.2-PCCDI2017-0701.

\section{References}

[1] Adb El Baky, H., El Baz, F.K., El Baroty, G., Evaluation of Marine Alga Ulva lactuca L. as A Source of Natural Preservative Ingredient, Electronic Journal of Environmental, Agricultural and Food Chemistry 3(11):434-444, 2008

[2] Analytik Jena AG, Germany, Procedure for the determination of the antioxidative capacity of lipid-soluble substances with the Photochem, 2004

[3] AOAC. Official Methods of Analysis. Association of Official Analytical Chemists, 16th Ed., K Hlrich. Arlington, Virginia, 1995

[4] Bakker, F.T., Olsen, J. L., Stam, W.T. , Global phylogeography in the cosmopolitan species Cladophora vagabunda (Chlorophyta) based on nuclear rDNA internal transcribed spacer sequences, Eur. ]. Phycol. (1995), 30: 197-208

[5] Biris-Dorhoi, E.-S., Tofana, M., Chis, S.M., Lupu, C.E., Negreanu-Pirjol, T., Wastewater treatment using marine algae biomass as pollutants removal, Revista de Chimie (Bucharest), vol. 69, No. 5, 2018, pp. 1089-1098 
[6] Biris-Dorhoi, S.-E., Tofana, T., Popoviciu, D.R., Negreanu-Pirjol, T., Oxidative stress evaluation in organic pollution conditions on some marine algae species, Journal of Environmental Protection and Ecology, vol. 19, no. 2 (2018), p. 592-600

[7] Bucur Arpenti, M., Negreanu-Pîrjol, T., Ehlinger, T., Paraschiv, G.M., Tofan, L., Heavy Metal Content Analysis of Siutghiol Lake Water and Sediment to Assess its Pollution Level, Rev. Chim. (Bucharest), 65, 9, 2014, p. 1108

[8] Cadar, E., Tomescu, A., Negreanu-Pirjol, B. S., Journal of Science and Arts, 3, 533-538, 2017

[9] Döll, Michaela, Das Antioxidantienwunder, Herbig, 2003

[10] El Sayed H. El Ashry, Atta-ur-Rahman, Choudhary, M. I., Kandil, S.H., El Nemr, A., Gulzar, T., Shobier, A. H., Studies on the constituents of the green alga Ulva lactuca, Chemistry of Natural Compounds, Vol. 47, No. 3, 2011

[11] Elenkov, I., Stefanov, K., Dimitrova-Konaklieva, S., Popov, S., Effect of salinity on lipid composition of Cladophora vagabunda, Phytochemistry 42(1):3944 May 1996

[12] Ivanova, V., Stancheva, M., Merdzhanova, A., Fatty acids composition of macroalgae from Bulgarian Black Sea coast, Ovidius University Annals of Chemistry Volume 23, Number 1, p. 35-40, 2012

[13] Killenberg-Jabs, M., Antioxidantienbestimmung als Parameter in der Nahrungsmittelanalytik; BIOforum 3; 2001; (2-3).

[14] Le Tutour, B., Antioxidative activities of algae extracts, synergic effects with vitamina E, Phytochem. 29(12), 3759-3765, 1990

[15] Lichtenthaler, H.K., Buschmann, C., Chlorophylls and carotenoids:

Measurement and characterization by UV-VIS spectroscopy, in R.E. Wrolstad (ed.), Current Protocols in Food Analytical Chemistry, John Wiley \& Sons Inc., Hoboken, 2001, F4.3: 1-8

[16] Messyasz, B., Leska, B., Fabrowska, J., Pikosz, M., Roj, E., Cieslak, A., Schroeder, G., Biomass of freshwater Cladophora as a raw material for agriculture and the cosmetic industry, Open Chem., licensee De Gruyter Open, 2015; 13: 1108-1118

[17] Miazek, K., Chlorophyll extraction from harvested plant material, in ČVUT Praha, Fakulta Strojní, Chemické potravinářské strojnictví, Procesní technika, 2011, http://chps.fsid.cvut. cz/pt/2011/pdf/1100011-1.pdf [18] Negreanu-Pîrjol, B., Negreanu-Pîrjol, T., Paraschiv, G., Bratu, M., Sîrbu, R., Roncea, F., Meghea, A., Physical-chemical characterization of some green and red macrophyte algae from Romanian Black Sea littoral, Scientific Study \& Research-Chemistry \& Chemical Engineering, Biotechnology, Food industry, 12 (2), p. $173-184,2011$ 
[19] Negreanu-Pîrjol, T., Negreanu-Pîrjol, B., Sîrbu, R., Paraschiv, G., Meghea, A., Comparative studies regarding the antioxidative activity of some therapeutic marine algae species along Romanian Black Sea Coast, Journal of Environmental Protection and Ecology, vol. 13, No. 3A, p. 1744-1750, 2012

[20] Negreanu-Pîrjol, T., Sîrbu, R., Bechir, A., Negreanu-Pîrjol, B., Leca, M., Studii comparative privind activitatea antioxidantă şi conţinutul de metale grele din unele specii de alge marine cu importanţă terapeutică din arealul românesc al Mării Negre, Rev. Med. Chir. Soc. Med. Nat. din Iaşi, vol. 112, nr. 2, Supliment nr. 1, p. $364-368,2008$

[21] Popov, I., Lewin, G., Antioxidative Homeostasis: Characterization by Means of Chemiluminescent Technique, Methods in Enzymology, Oxidants and Antioxidants, Part B, Ed. Lester Packer, Academic Press, New York, 300, 437, 1999

[22] Shahidi, F., Ho, C.T., Phytochemicals and Phytopharmaceuticals, AOCS Press, Champaign, USA, 153, 1999

[23] Sîrbu, R., Negreanu-Pîrjol, T., Paris, S., Negreanu-Pîrjol, B. Ş., Jurja, S., Tomescu, A., Important bioactive compounds from marine algae - potential source of pharmaceutical industry, 14th International Multidisciplinary Scientific GeoConferences „Surveying Geology \& mining Ecology Management - SGEM 2014", 17 - 26 June 2014, Albena, Bulgaria, Conference Proceedings, Volume I, Section Advances in Biotechnology, p. 381 - 388

[24] Sirbu, R., Negreanu-Pirjol, T., Paris, S., Negreanu-Pirjol, B.S., Jurja, S., Tomescu, A., Important bioactive compounds from marine algae - potential source of pharmaceutical industry, 14th International - SGEM Conference Proceedings, Bulgaria, I, 381-388, 2014.

[25] Winnefeld, K., Sperschneider, H., Thiele, R., Peiker, G., Klinger, G., Antioxidantienstatus, Analytik und klinische Bedeutung; GIT 